\title{
Expression patterns of cytokines, p53 and nitric oxide synthase isoenzymes in corpora lutea of pseudopregnant rabbits during spontaneous luteolysis
}

\author{
Cristiano Boiti, Gabriella Guelfi, Massimo Zerani ${ }^{1}$, Danilo Zampini, Gabriele Brecchia \\ and Anna Gobbetti ${ }^{1}$ \\ Dipartimento di Scienze Biopatologiche Veterinarie, Università di Perugia, S. Costanzo 4, 06126 Perugia, Italy \\ and ${ }^{1}$ Dipartimento di Biologia Molecolare, Cellulare e Animale, Università di Camerino, Camerino, Italy \\ Correspondence should be addressed to C Boiti; Email: cristiano.boiti@unipg.it
}

\begin{abstract}
The gene expressions for macrophage chemoattractant protein-1 (MCP-1), interleukin (IL)-1ß, IL-2 and p53 were examined by semi-quantitative RT-PCR in corpora lutea $(\mathrm{CL})$ of rabbits during spontaneous luteolysis at days 13, 15, 18 and 22 of pseudopregnancy. In the same luteal tissue, total activity of nitric oxide (NO) synthase (NOS) and genes for both endothelial (eNOS) and inducible (iNOS) isoforms were also analysed. From day 13 to 15, MCP-1 and IL-1 $\beta$ mRNA levels rose $(P \leq 0.01)$ almost 2-fold, and the transcript for p53 almost 8-fold, but then all dropped $(P \leq 0.05)$ from day 18 onward. IL-2 mRNA abundance was higher $(P \leq 0.01)$ on day 13 and then gradually declined. During luteolysis, eNOS mRNA decreased $40 \%(P \leq 0.05)$ by day 15, but thereafter remained unchanged, while iNOS mRNA was barely detectable and did not show any clear age-related pattern throughout the late luteal stages. Total NOS activity progressively increased $(P \leq 0.01)$ from day 13 to 18 of pseudopregnancy and then dropped to the lowest $(P \leq 0.01)$ levels on day 22. Luteal progesterone content also declined during $\mathrm{CL}$ regression from 411 to $17 \mathrm{pg} / \mathrm{mg}$ found on days 13 and 22 respectively, in parallel with the decrease in blood progesterone concentrations. These data further support a physiological role of $\mathrm{NO}$ as modulator of luteal demise in rabbits. Locally, luteal cytokines may be involved in the up-regulation of NOS activity, while downstream NO may inhibit steroroidogenesis and induce expression of p53 gene after removal of the protective action of progesterone.

Reproduction (2004) 127 229-238
\end{abstract}

\section{Introduction}

Luteolysis involves both functional and structural changes along a complex and streamlined process that ends with the complete demise of corpora lutea $(\mathrm{CL})$. In rabbits, a reflex ovulator, this mechanism comes into play either at the end of gestation or after an infertile mating to shorten the life span of unnecessary $C L$ and reduce the length of pseudopregnancy (Carlson \& Gole 1978). In this species, luteolysis normally begins on approximately day $12-14$ of pseudopregnancy and is completed around day 18 when progesterone declines to the basal value (Browning et al. 1980).

In rabbits, several factors are now recognised to regulate, via paracrine and/or autocrine mechanisms, the life span of $\mathrm{CL}$ from formation to regression (Niswender et al. 2000, Webb et al. 2002). Among these, convincing evidence suggests that nitric oxide (NO), produced by the action of different NO synthase (NOS) isoenzymes (Schmidt \& Walter 1994), may modulate different ovarian functions and luteal regression (Dixit \& Parvizi 2001, Tamanini et al. 2002). In rabbits, $\mathrm{NO}$ inhibits in vitro progesterone release by $\mathrm{CL}$ at different stages of pseudopregnancy (Gobbetti et al. 1999), and NOS activity is up-regulated by prostaglandin F- $\alpha$ (PGF2 $\alpha$ ) via the phospholipase C/protein kinase C pathway (Boiti et al. 2000). More recently, a number of reports on the regulation of both NOS activity and expression of genes encoding endothelial and inducible NOS isoforms (eNOS and iNOS) during both luteal development (Boiti et al. 2002) and PGF2 $\alpha$-induced luteolysis (Boiti et al. 2003) in rabbits have been produced. Collectively, these studies provided the first evidence that $\mathrm{NO}$ may serve as a regulator of luteal steroidogenesis and act as a potential effector of luteal regression prematurely induced by PGF $2 \alpha$. Moreover, NO deficiency via long-term treatment with L-NAME, a NOS inhibitor, partially blocked the regression mechanism induced by PGF $\alpha$ and extended luteal function, thus indirectly confirming the role of $\mathrm{NO}$ in the luteolytic process (Boiti et al. 2003). 
According to some recent views, luteolysis might be regarded as an immune-mediated event leading to apoptosis (Tilly 1996), and in this context, the cytokines normally found also in CL of rabbits (Krusche et al. 2002) may exert a physiological role in luteal demise (Del Vecchio \& Sutherland 1997, Penny 2000, Pate \& Keyes 2001). Increasing evidence indicates that some cytokines may suppress or induce apoptosis (Lotem \& Sachs 1999) as well as regulate NOS expression and activity in different ways, depending on cell type, cytokines and NOS isoform (Forstermann et al. 1995). Interestingly, a variety of genes for cytokines may be downstream targets of the short-lived secondary messenger NO (Torres \& Forman 2000) produced by resident luteal cells or by the heterogeneous population of accessory immune cells present within the CL (Bagavandoss et al. 1990). At the same time, NO may promote the intracellular mechanisms of the apoptotic pathways or inhibit its activation (Kim et al. 1999).

Thus, to better characterise some of those factors that may regulate NOS activity, or respond to NO, the objectives of this study were to (i) examine whether the gene expression patterns for $\mathrm{p} 53$, whose product triggers apoptosis, and different cytokines, including macrophage chemoattractant protein-1 (MCP-1), interleukin (IL)-1 $\beta$ and IL-2, are regulated during the spontaneous luteolytic process in rabbits, (ii) investigate the relationship between both luteal eNOS and iNOS expression levels and NOS activity, and (iii) correlate NOS activity with luteal and plasma progesterone content. Since up to day 12 of pseudopregnancy NOS activity was not found to change (Boiti et al. 2003), for this ex vivo model, $\mathrm{CL}$ were collected throughout late luteal stages at days 13, 15, 18 and 22 of pseudopregnancy, across both functional and structural luteolysis.

\section{Materials and Methods}

\section{Materials}

Random hexamer primers, deoxyribonuclease I (DNAase I Amp Grade), RNAse $\mathrm{H}^{-}$reverse transcriptase (Superscript II), E. coli RNase $\mathrm{H}$ and DNA ladders were obtained from Invitrogen (S. Giuliano Milanese, Milan, Italy). The reagent for isolation and purification of total RNA (TRIzol), Taq DNA polymerase (Platinum), RNAse-free tubes and RNAse-free water and deoxy-NTPs were also acquired from Invitrogen. Primers for $18 \mathrm{~S}$ rRNA and corresponding competimers (QuantumRNA 18S Internal Standards) were obtained from Ambion (Austin, TX, USA), while those for each target NOS RNA were custom obtained from Invitrogen. Primers for mRNAs of p53 and cytokines MCP-1, IL-1 $\beta$ and IL-2 were supplied by Maxim Biothec Inc. (San Francisco, CA, USA). The kit for the assay of proteins was obtained from Bio-Rad Laboratories (Segrate, Milan, Italy). $\left[2,3-{ }^{3} \mathrm{H}\right] \mathrm{L}$-arginine, having a specific activity of $30-40$ $\mathrm{Ci} / \mathrm{mmol}$, and all other chemicals were from Sigma
(St Louis, MO, USA). [1, 2, 6, $\left.7-{ }^{3} \mathrm{H}\right]$ progesterone was purchased from Amersham Biosciences (Amersham Biosciences Ltd, Little Chalfont, Bucks, UK), while nonradioactive progesterone and antiserum came from Sigma. The NOS detectTM Assay Kit was purchased from Alexis Corp. (Läufelfingen, Switzerland). All other chemicals and reagents were pure grade and obtained locally. The following hormonal preparations were administered: gonadotrophin-releasing hormone $(\mathrm{GnRH})$ analogue (Receptal; Hoechst-Roussel Vet, Italy) and pregnant mare serum gonadotrophin (PMSG) (Folligon; Intervet, Italy).

\section{Animals, hormonal regimen and luteal tissue collection}

The protocols involving the care and use of animals for these experiments were approved by the Bioethic Committee of the University of Perugia.

Luteal tissue was obtained from unmated New Zealand White (HY/CR strain) rabbits (Charles River Italia, Lecco, Italy), 5 months of age, weighing $3.5-3.8 \mathrm{~kg}$. The animals, caged individually in quarters of the University of Perugia Central Animal Facility, were maintained under controlled conditions of light ( $14 \mathrm{~h}$ light: $10 \mathrm{~h}$ darkness) and temperature $\left(18{ }^{\circ} \mathrm{C}\right)$, and provided with commercial rabbit chow and tap water freely. All rabbits received an i.m. injection of $20 \mathrm{IU}$ of PMSG followed 3 days later by an i.m. injection of $0.8 \mu \mathrm{g} \mathrm{GnRH}$ to induce pseudopregnancy. The day of $\mathrm{GnRH}$ injection was designated day 0 . This ovulation procedure was effective in generating an average of 14 or $15 \mathrm{CL}$ per rabbit.

At days 13, 15, 18 and 22 of pseudopregnancy, five rabbits for each day were killed by cervical dislocation. CL were promptly excised from ovaries and rinsed with RNAse-free PBS. Non-luteal tissue was carefully dissected away with fine forceps under stereoscopic magnification. The $\mathrm{CL}$ harvested from each rabbit were immediately stored at $-80^{\circ} \mathrm{C}$ until processed for the enzymatic studies of total NOS activity, gene expression and progesterone content. From each rabbit, blood samples for progesterone assay were collected by venous puncture of the marginal ear vein, on the same days until immediately prior to killing. The samples were centrifuged at $3000 \mathrm{~g}$ for $15 \mathrm{~min}$ and plasma stored frozen until assayed for progesterone concentrations to assess the functional status of the ovarian $\mathrm{CL}$. For the purpose of this work functional luteolysis was defined as a $50 \%$ decline of plasma progesterone from previous values, while complete luteolysis as the failure of $\mathrm{CL}$ to secrete progesterone so that blood levels decrease below $1.0 \mathrm{ng} / \mathrm{ml}$, which are found in oestrous rabbits.

\section{RNA extraction and reverse transcription}

For each rabbit, total RNA was extracted from a pool of eight to ten $\mathrm{CL}$, which were homogenised using Omni- $\mu \cup$ (Analytical Control; Cinisello Balsamo, Milano, Italy) in $1 \mathrm{ml}$ of the solution provided with TRIzol using the procedure as described by the manufacturer. 
Concentration of total RNA $\left(\mathrm{OD}_{250}\right)$ and purity $\left(\mathrm{OD}_{260 / 280}, \mathrm{OD}_{260 / 230}\right)$ was determined spectrophotometrically with a BioPhotometer (Eppendorf srl, Milan, Italy). The integrity of each sample was assessed by electrophoresis of an aliquot of $3 \mu \mathrm{g}$ RNA in agarose formaldeyde gel using ethidium bromide staining. Genomic DNA contamination was prevented by treatment with deoxyribonuclease I (DNAase I Amp Grade) according to the manufacturer's instructions.

Five micrograms of total RNA $(1 \mu \mathrm{g} / \mu \mathrm{ml})$ were reverse transcribed into cDNA in a $20 \mu \mathrm{l}$ final reaction mixture in the presence of Superscript II reverse transcriptase following the manufacturer's procedure. The reverse transcription mixture consisted of $1 \mathrm{mmol} / \mathrm{l} \mathrm{d}-\mathrm{NTPs}$ and $100 \mathrm{ng}$ random hexamer primers. The reaction was carried out for $50 \mathrm{~min}$ at $45^{\circ} \mathrm{C}$ and was then inactivated by heating at $70^{\circ} \mathrm{C}$ for $15 \mathrm{~min}$. To remove the cRNA to the cDNA, $1 \mu \mathrm{l}$ E. coli $\mathrm{RNase} \mathrm{H}$ was added to the mixture and incubated at $37^{\circ} \mathrm{C}$ for $30 \mathrm{~min}$. Genomic DNA contamination was checked by carrying samples through PCR procedure without reverse transcriptase. The reverse transcription products were stored at $-20^{\circ} \mathrm{C}$.

\section{Multiplex RT-PCR amplification}

An aliquot $(1.0 \mu \mathrm{l})$ of cDNA was used as a template for the subsequent semi-quantitative PCR amplification reaction containing two primer sets, one for the target gene (eNOS, iNOS, MCP-1, IL-1 $\beta$, IL-2 and p53) and the other for a housekeeping gene (18S rRNA). Two sets of $18 \mathrm{~S}$ housekeeping primers ( 324 and $489 \mathrm{bp}$ ) were used for the best discrimination of the target/housekeeping bands following gel electrophoresis.

The PCR reaction $(25.0 \mu \mathrm{l})$ was performed with $0.2 \mu \mathrm{l}$ Taq DNA Polymerase $(5 \mathrm{U} / \mu \mathrm{l}), 1.0 \mu \mathrm{l}$ dNTPs $(10 \mathrm{mmol} / \mathrm{l})$, $5.0 \mu \mathrm{l} \mathrm{Taq}$ buffer $10 \times, 3.0 \mu \mathrm{l}$ mixed primers for each target gene (MCP-1, IL-1 $\beta$, IL-2 and p53) and 18 Sousekeeping gene (489 bp) with competimers $(2: 8 \mathrm{v} / \mathrm{v})$.

Sequences for custom primers or their code number (Maxim Biotech Inc.) were: MCP-1 (accession no. M57440, code no. CSM0003-MCP-1), product size $292 \mathrm{bp}$; IL-1 $\beta$ (accession no. M26295, code no. CSM0003-IL-1), product size $183 \mathrm{bp}$; IL-2 (accession no. AF068057, code no. CSM0003-IL2), product size $111 \mathrm{bp}$, forward 5'-AACTCAAACCTCTGGAGGAAGTGC-3', reverse 5'-TCGATGCTGAGATGATGCTTTGACA-3'; p53 (accession no. 90592, code no. CSM004-p54), product size 300 bp; $18 \mathrm{~S}$ (accession no. 10098): product size $489 \mathrm{bp}$, forward 5'-TCAAGAACGAAAGTCGGAGGTT-3', reverse 5'-GGACATCTAAGGGCATCA-3'.

For the PCR of eNOS (or iNOS), $1.0 \mu \mathrm{l}(10 \mu \mathrm{mol} / \mathrm{l})$ of mixed primers for each target gene, both forward and reverse, were co-amplified with $18 \mathrm{~S}$ housekeeping primers $(324 \mathrm{bp})$, in the same master mix previously described. The primer sequences used were: eNOS (accession no. AF 287158), product size $485 \mathrm{bp}$, forward 5'-CAGTGTCCAACATGCTGCTGGAAATTG-3', reverse 5'-TAAAGGTCTTCTTCCTGGTGATGCC-3'; iNOS (accession no. U85094), product size $537 \mathrm{bp}$, forward 5'CAGGACCACACCCCCTCGGA-3', reverse $5^{\prime}$-AGCCACATCCCGAGCCATGC-3'; $18 \mathrm{~S}$ (accession no. M 10098), product size $324 \mathrm{bp}$, forward 5'-AGGAATTGACGGAAGGGCAC-3', reverse 5'-GTGCAGCCCCGGACATCTAAG-3'.

The semi-quantitative PCR reactions were carried out as reported previously (Boiti et al. 2002). Preliminary experiments were carried out to establish the optimal ratio between $18 \mathrm{~S}$ primers and their competimers, as well as the range of cycles. Between 30 and 40 cycles both target and 185 products were in a linear exponential phase of amplification (data not shown). To minimise errors, within each experiment, the target gene was co-amplified with housekeeping $18 \mathrm{~S}$ primers at the same PCR cycle. The $18 \mathrm{~S}$ rRNA is an ideal internal control for quantitative RNA analysis because its expression remains invariant across tissues and treatments, although its relatively high abundance makes it difficult to use in RT-PCR experiments because target mRNA species are by far less abundant. However, by mixing appropriate amounts of $18 \mathrm{~S}$ primers with their competimers, primers modified only at their $3^{\prime}$ ends to block extension by DNA polymerase, the PCR amplification efficiency of $18 \mathrm{~S}$ cDNA can be reduced to a level roughly similar to that of the gene under study. To summarise, amplification was performed on a thermal cycler (GeneAmp, PCR System; Perkin-Elmer Biosystem, Foster City, CA, USA). All PCR reactions consisted of a first denaturating cycle at $94^{\circ} \mathrm{C}$ for $75 \mathrm{~s}$, followed by an amplification profile of 35 reaction cycles with a first denaturating cycle at $94^{\circ} \mathrm{C}$ for $15 \mathrm{~s}$, followed by annealing at $60^{\circ} \mathrm{C}$ for $30 \mathrm{~s}$ and extension at $72{ }^{\circ} \mathrm{C}$ for $45 \mathrm{~s}$, and a final extension step at $72^{\circ} \mathrm{C}$ for $10 \mathrm{~min}$. Within each experiment and for each gene analysed, the complete set of samples was processed in parallel in a single PCR using aliquots of the same PCR master mix. Each set of determinations was performed in triplicate.

\section{Analysis of amplification products}

The amplified PCR-generated products $(20 \mu \mathrm{l}$ of $25 \mu \mathrm{l}$ total reaction volume) were analysed by electrophoresis on $2 \%$ agarose gel using ethidium bromide staining. One product for each day of pseudopregnancy was electrophoresed on a single gel together with a negative control that contained no RNA and a standard DNA ladder. The gel images were acquired by using a Kodak DC290 digital camera. The background-corrected band intensities (absolute optical densities subtracted by the background levels from corresponding lanes) for each PCR product were quantified using Quantity One software (Bio-Rad Laboratories, Hercules, CA, USA). To evaluate the temporal changes in relative levels of mRNAs, the band intensities for the target genes of interest obtained from each aliquot of PCR products were normalised against those of the housekeeping $18 \mathrm{~S}$ mRNA co-amplified product in the same aliquot. Values 
were expressed as arbitrary units of relative abundance of the specific target genes.

\section{NOS activity determination}

NOS activity was determined by monitoring the conversion of $\left[{ }^{3} \mathrm{H}\right] \mathrm{L}$-arginine (Sigma) into $\left[{ }^{3} \mathrm{H}\right] \mathrm{L}$-citrulline with a commercial NOS assay kit, according to the experimental protocol previously described (Boiti et al. 2000). Total NOS luteal activity of each rabbit was independently assayed in three $\mathrm{CL}$ randomly selected from the corresponding pool.

\section{Progesterone assay}

Progesterone concentrations in plasma samples and luteal tissue were determined by RIA, using specific antibody according to the procedure reported elsewhere (Boiti et al. 2003). Progesterone was extracted with ethyl ether from plasma or $\mathrm{CL}$, after homogenisation in PBS in a Dounce homogeniser. The progesterone content of $\mathrm{CL}$ was expressed as ng/mg wet weight of luteal tissue. The assay sensitivity was $10 \mathrm{pg} / \mathrm{ml}$; intra-assay and inter-assay coefficients of variations were 6 and $11 \%$ respectively.

\section{Statistical analysis}

All experiments were repeated three times and means \pm s.E.M. of values (arbitrary expression units, progesterone concentrations and radioactivity) are given as a function of luteal age for the number of separate cases as reported in figure legends. The ratios of each PCR product for a target gene (MCP-1, IL-1 $\beta$, IL-2, p53, eNOS and iNOS) normalised against the $18 \mathrm{~S}$ co-amplified product were analysed by two-factor ANOVA (Sokal \& Rohlf 1981) by taking into account the day of pseudopregnancy and gel as the two sources of variability, followed by a NewmanKeuls multi-comparison post-test.

Data relative to the time course of progesterone concentrations in plasma and luteal tissue and those of NOS activity during late pseudopregnancy and spontaneous luteolysis were analysed by ANOVA followed by Duncan's multiple range test (Duncan 1955). The relationship between total NOS luteal activities and progesterone levels was determined by correlation analysis. A value of $P<0.05$ was considered significant.

\section{Results}

To study the time-dependent course of mRNA levels encoding the gene of interest during spontaneous luteolysis, samples of total RNA, extracted from CL of individual rabbits at different time points, were analysed by semiquantitative multiple RT-PCR, using specific primers. In each PCR reaction, 18S rRNA was co-amplified and used as an internal standard for the calculation of the relative abundance of mRNA for the target genes. The expression of $18 \mathrm{~S}$ rRNA in rabbit $\mathrm{CL}$ remained fairly constant, independently of the luteal phases. The corresponding base pair amplification products obtained using primers designed for each gene matched the expected sizes (see Figs 1-5).
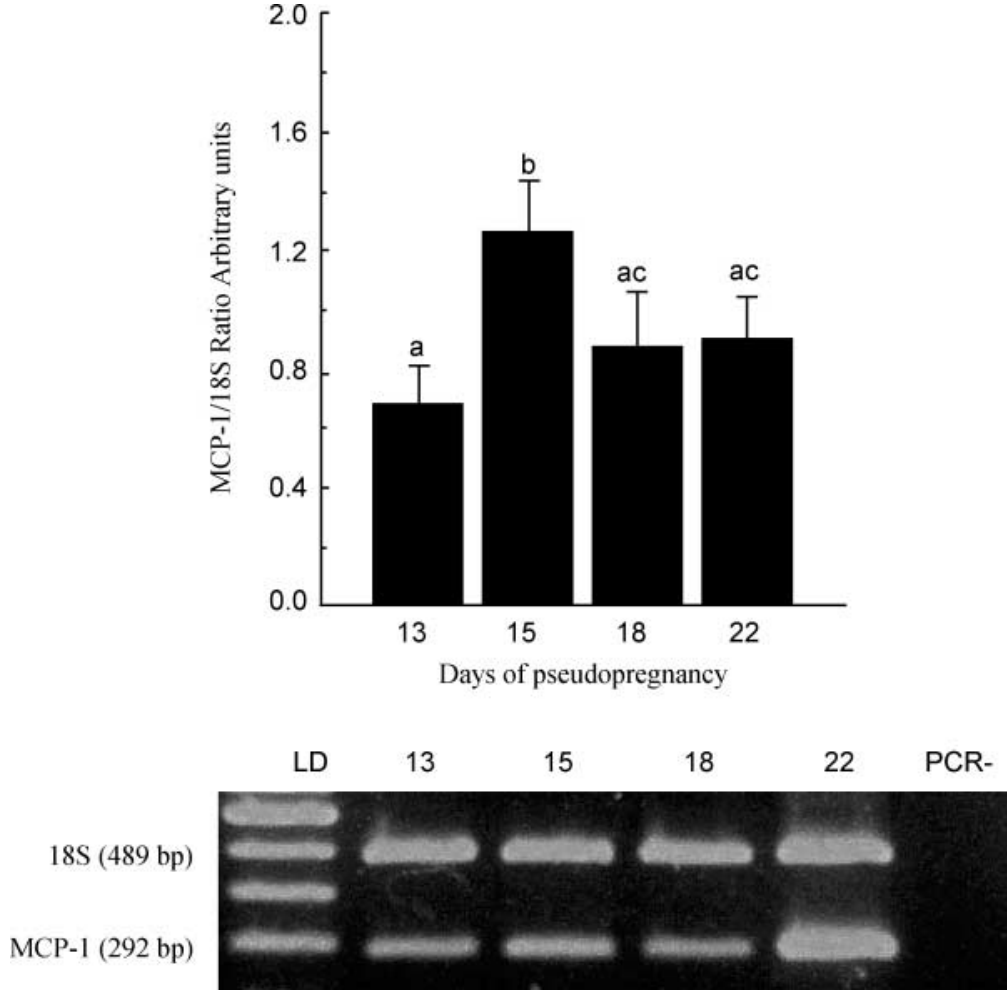

Reproduction (2004) 127 229-238
Figure 1 Expression profile of MCP-1 mRNA in CL of rabbits obtained at days 13, 15, 18 and 22 of pseudopregnancy. The lower panel shows a representative photograph of a $2 \%$ agarose ethidium bromide-stained gel used to analyse the PCR products. The sizes of the amplified products are shown on the left of the gel. LD is the kilobase DNA marker while lane PCR - represents a negative control of non-reverse-transcribed RNA submitted to PCR amplification. The other lanes identify the corresponding days of pseudopregnancy. The upper panel shows the data derived from densitometric analyses of the gels. For each luteal age, the values (means \pm S.E.M.) Combine the results from five different rabbits and are reported in arbitrary units of MCP-1 mRNA relative to that of $18 \mathrm{~S}$ used as internal standard. Different letters above bars indicate a significantly different value $(P \leq 0.05)$. 


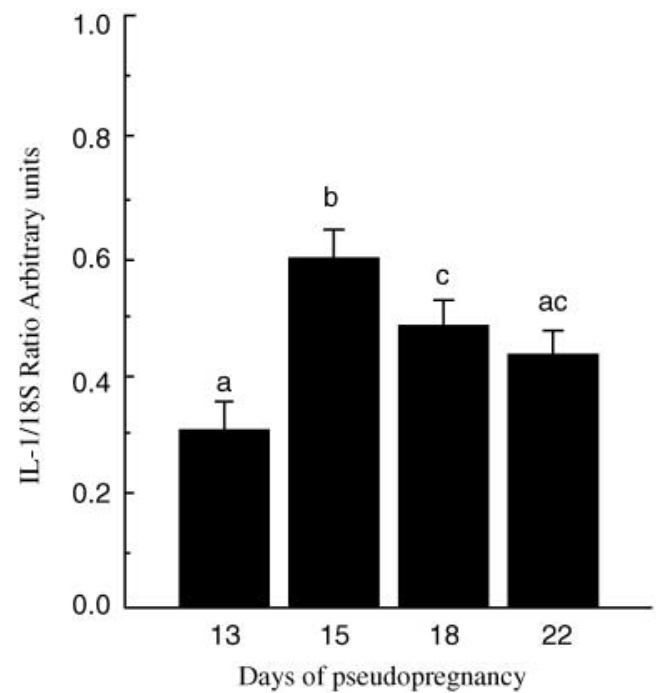

LD PCR13 15 18 22

18S (489 bp)
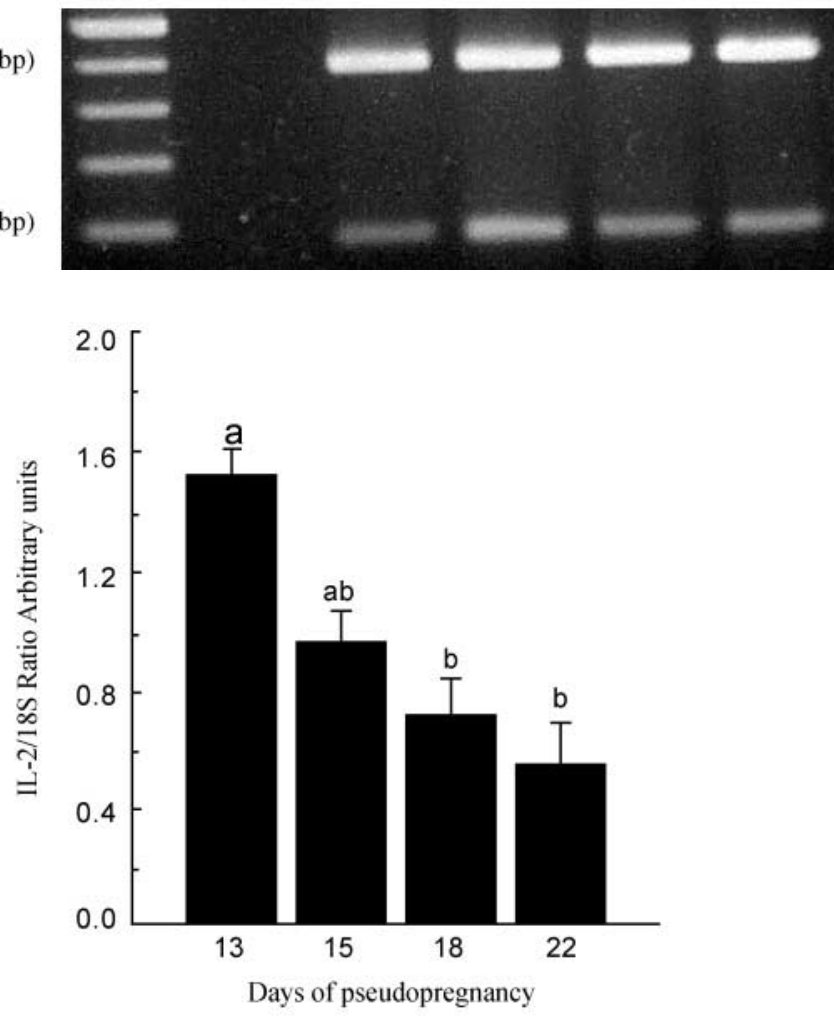

LD 13 15 18 22

PCR-

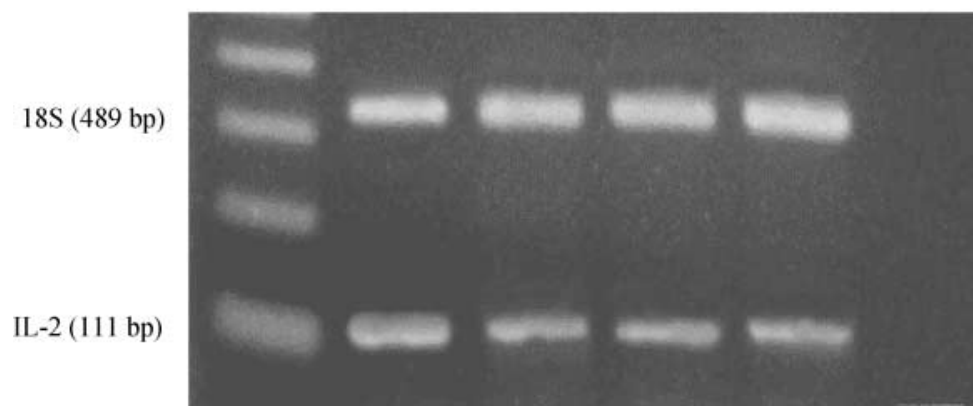

Figure 2 Expression pattern and levels of mRNA encoding IL-1 $\beta$ gene in CL of rabbits obtained at days 13,15 , 18 and 22 of pseudopregnancy during luteal regression. The PCR products were analysed by a $2 \%$ agarose ethidium bromide-stained gel. The lower panel shows a representative photograph of a gel. The sizes of the amplified products are shown on the left of the gel. LD is the kilobase DNA marker while lane PCR - represents a negative control of non-reverse-transcribed RNA submitted to PCR amplification. The other lanes identify the corresponding days of pseudopregnancy. The upper panel shows the data derived from densitometric analyses of the gels. For each luteal age, the values (means \pm S.E.M.) combine the results from five different rabbits and are reported in arbitrary units of IL-1 $\beta$ mRNA relative to that of $18 \mathrm{~S}$ used as internal standard. Different letters above bars indicate a significantly different value $(P \leq 0.05)$.
Figure 3 Expression profile and relative abundance of IL2 mRNA in CL of rabbits obtained at days 13, 15, 18 and 22 of pseudopregnancy. The PCR products were analysed by a $2 \%$ agarose ethidium bromide-stained gel (lower panel). The sizes of the amplified products are shown on the left of the gel. LD is the kilobase DNA marker while lane PCR- represents a negative control of non-reversetranscribed RNA submitted to PCR amplification. The other lanes identify the corresponding days of pseudopregnancy. The upper panel shows the data derived from densitometric analyses of the gels. For each luteal age, the values (means \pm S.E.M.) combine the results from five different rabbits and are reported in arbitrary units of IL-2 mRNA relative to that of $18 \mathrm{~S}$ used as internal standard. Different letters above bars indicate a significantly different value $(P \leq 0.05)$. 


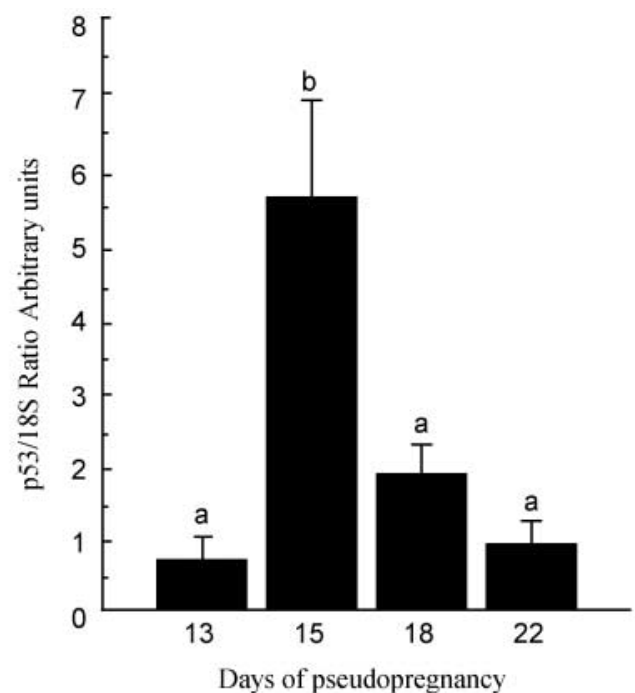

LD PCR13 15 18 22

18S (489 bp)

Figure 4 Expression profile and relative abundance of p53 mRNA in CL of rabbits obtained at days 13, 15, 18 and 22 of pseudopregnancy. The PCR products were analysed by a $2 \%$ agarose ethidium bromide-stained gel (lower panel). The sizes of the amplified products are shown on the left of the gel. LD is the kilobase DNA marker while lane PCR - represents a negative control of non-reverse-transcribed RNA submitted to PCR amplification. The other lanes identify the corresponding days of pseudopregnancy. The upper panel shows the data derived from densitometric analyses of the gels. For each luteal age, the values (means \pm S.E.M.) combine the results from five different rabbits and are reported in arbitrary units of p53 mRNA relative to that of $18 \mathrm{~S}$ used as internal standard. Different letters above bars indicate a significantly different value $(P \leq 0.05)$.

\section{Gene expression of mRNA for luteal cytokines and p53}

MCP-1 mRNA levels rose 2 -fold $(P \leq 0.01)$ from day 13 to 15 of pseudopregnancy, but then dropped $(P \leq 0.05)$ by day 18 onward (Fig. 1). The gene transcript for IL-1 $\beta$ exhibited a similar pattern (Fig. 2) with a peak in its expression at day 15 of pseudopregnancy when its relative abundance was $90 \%$ higher $(P \leq 0.01)$ than that found at day 13 . From day 18 of pseudopregnancy onward, IL-1 $\beta$ mRNA levels gradually fell. IL-2 relative mRNA abundance (Fig. 3) was higher $(P \leq 0.05)$ on day 13 and then gradually declined during the course of luteal regression.

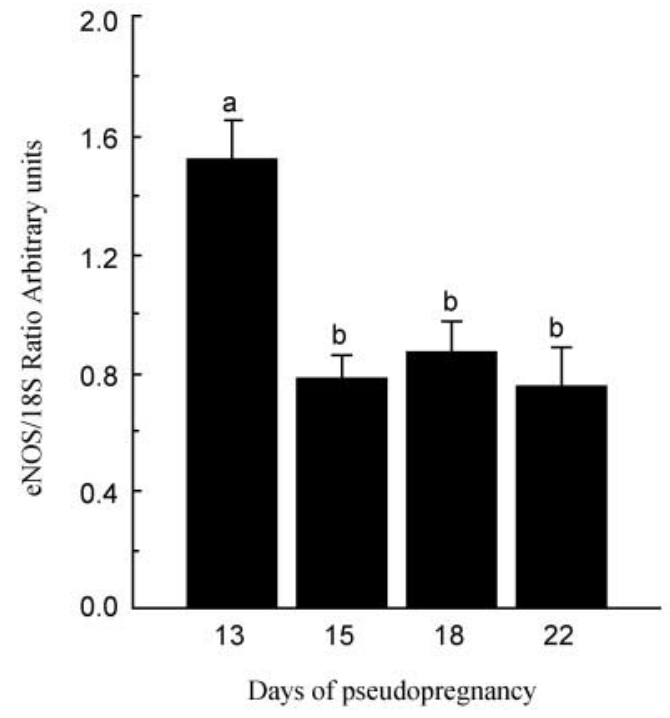

LD

13

15

18

22

PCR-

eNOS 485 bp

$18 \mathrm{~S} 324 \mathrm{bp}$

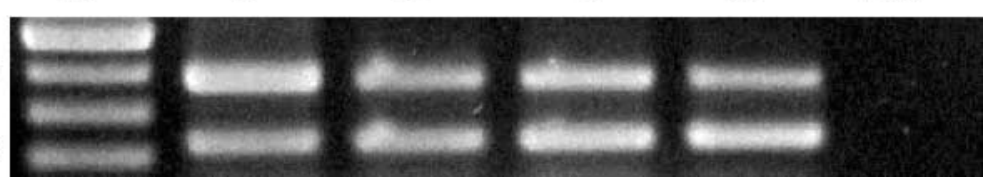

Figure 5 Gene expression patterns of eNOS mRNA in CL of rabbits harvested at days 13, 15, 18 and 22 of pseudopregnancy. The lower panel is a representative photograph of a typical $2 \%$ agarose, ethidium bromide-stained gel, showing the presence of the expected $485 \mathrm{bp}$ products yielded after RT-PCR using primers for target eNOS and 18S. Lane LD is the kilobase DNA marker, lane PCR - represents a negative control of non-reverse-transcribed RNA submitted to PCR amplification, while the other lanes identify the corresponding days of pseudopregnancy. The upper panel summarises the data derived from densitometric analyses of the gels from the experiments of natural luteolysis. The values (means \pm S.E.M.) combine the results from five different rabbits for each luteal age and are reported in arbitrary units of eNOS mRNA relative to that of $18 \mathrm{~S}$ used as internal standard. Different letters above bars indicate a significantly different value $(P \leq 0.05)$. 
The p53 mRNA levels markedly rose $(P \leq 0.01) 8$-fold from day 13 to 15 of pseudopregnancy and then gradually declined from day 18 onward $(P \leq 0.05)$ to the same levels found at day 13, before the onset of functional luteolysis (Fig. 4).

\section{Gene expression of NOS isoforms mRNA}

In the course of luteal regression, eNOS mRNA levels in $\mathrm{CL}$ decreased by almost $40 \%(P \leq 0.05)$ from day 13 to 15 , and then remained unchanged throughout the late luteal stages in both day 18 and $22 \mathrm{CL}$ (Fig. 5). During the same time interval, iNOS mRNA was barely detectable, ranging between $0.26 \pm 0.12$ and $0.15 \pm 0.04$ (arbitrary units), but no clear patterns in its steady state levels were observable (data not shown).

\section{Total NOS activity and progesterone}

During the late luteal phase of pseudopregnancy, total NOS activity progressively increased $(P<0.05) 2$-fold from day 13 to $18 \mathrm{CL}$ and then markedly dropped to the lowest levels in day $22 \mathrm{CL}$ (Fig. 6).

Luteal progesterone content decreased with the ageing of $\mathrm{CL}$ during late luteal phases, from $411 \mathrm{pg} / \mathrm{mg}$ wet weight on day 13 to $17 \mathrm{pg} / \mathrm{mg}$ on day 22 (Fig. 7A). The changes in NOS total activity were inversely correlated with decreases in luteal progesterone content on days 13, 15 and 18 of pseudopregnancy $(r=-0.92, P \leq 0.01)$.

Similarly, plasma progesterone concentrations, used as a marker of luteal functionality, markedly dropped $(P \leq 0.01)$ in rabbits from day 13 to 15 of pseudopregnancy $(12.3 \pm 1.5$ and $1.7 \pm 0.3 \mathrm{ng} / \mathrm{ml}$ respectively) and then

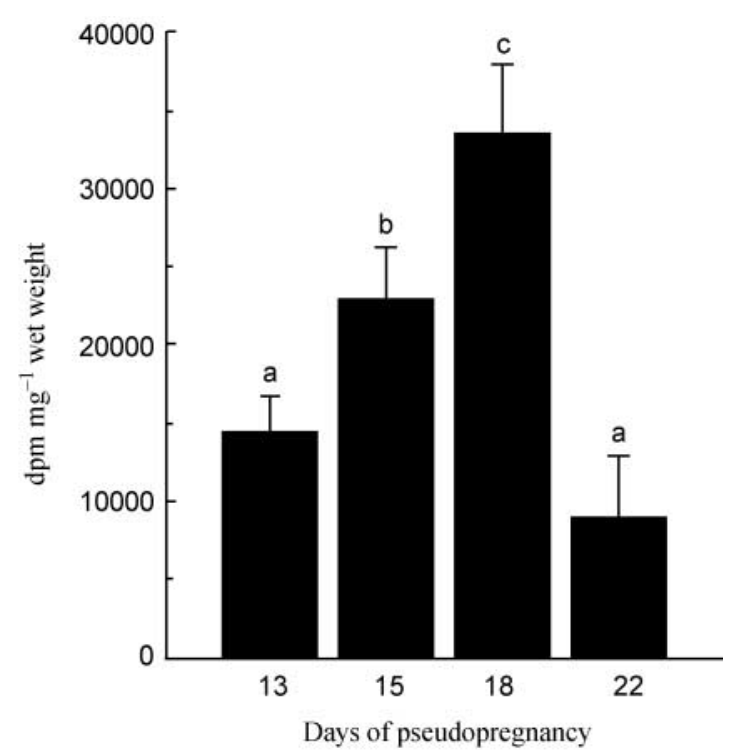

Figure 6 Changes in total NOS activity from day 13 to 22 of pseudopregnancy. Results refer to mg of wet tissue and represent means \pm S.E.M. of five combined values for each data point. Different letters above bars indicate a significantly different value $(P \leq 0.05)$. gradually decreased to the lowest values $(0.4 \pm 0.2 \mathrm{ng} / \mathrm{ml})$ found at day 22 (Fig. 7B).

\section{Discussion}

The main aim of this study was to verify whether the activity of NOS and the levels of genes encoding NOS isoforms, both eNOS and iNOS, and cytokines MCP-1, IL$1 \beta$ and IL-2 as well as p53 were dynamically regulated in $\mathrm{CL}$ of rabbits in the course of spontaneous luteolysis. In the present study, we have demonstrated for the first time that changes in luteal p53 gene transcription during spontaneous luteolysis are closely coupled with the upregulation of luteal NOS total activity and are coincident with progesterone decline. Moreover, the expression patterns of MCP-1, IL-1 $\beta$ and IL-2 suggest, although indirectly, that these cytokines may be involved in the regulation of NOS expression and activity in $\mathrm{CL}$, thus playing a role in their regression.

In the present study, the increased gene expression for luteal cytokines MCP-1 and IL-1 $\beta$ detected at day 15 of pseudopregnancy may reflect the increased traffic of different immune cell types, including macrophages associated with luteal demise (Bagavandoss et al. 1990, Naftalin et al. 1997, Krusche et al. 2002). In the rabbit CL, according to Bagavandoss et al. (1998), T lymphocytes precede the presence of macrophages. The influx of these $\mathrm{T}$ cells, therefore, may be responsible for the higher expression of IL-2 mRNA found in rabbit CL at day 13 of pseudopregnancy compared with older, regressing $\mathrm{CL}$. In this study, the temporal expression patterns of mRNAs for the cytokines here examined were different from those recently reported by Krusche et al. (2002) during functional and structural regression. However, besides the different hormonal protocols used for inducing ovulation, the diverse analytical approaches to measure mRNA abundance may partially explain this discrepancy. In our study, in fact, the relative gene expression levels were quantified with greater accuracy using the multiplex RT-PCR technique, by co-amplifying each target gene with $18 \mathrm{~S}$ rRNA as internal standard.

A 2- to 3-fold rise in NOS activity occurred at days 15 and 18 of pseudopregnancy during the transition of the $\mathrm{CL}$ from the late-luteal stage to functionally regressed $\mathrm{CL}$, as evidenced by the concomitant fall of both luteal progesterone content and plasma concentrations towards basal values. In the present study we have not attempted to differentiate the specific contribution to total bio-activity between the two isoforms. Therefore, it remains to be verified whether the increased production of $\mathrm{NO}$ observed during the course of luteolysis derives from eNOS or mainly from iNOS, as found in rats (Motta \& Gimeno 1997). Whereas eNOS enzyme does not depend upon new protein synthesis to rapidly synthesise and release $\mathrm{NO}$, iNOS is mainly regulated at the expression level, requiring new protein synthesis to catalyse the formation 

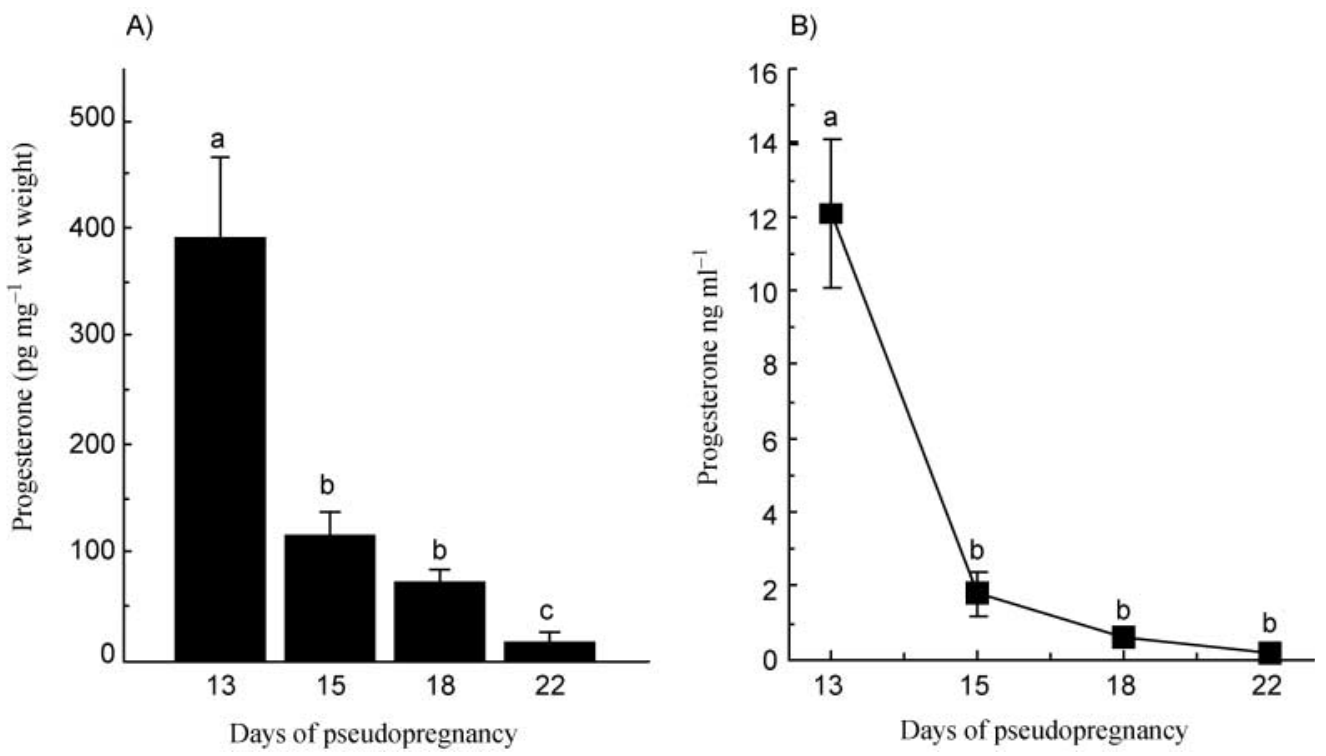

Figure 7 (A) Luteal progesterone content and (B) progesterone levels in blood throughout late luteal stages, from day 13 to 22 of pseudopregnancy. Results for luteal progesterone content refer to $\mathrm{mg}$ of wet tissue, while those for plasma progesterone concentrations refer to $\mathrm{ng} / \mathrm{ml}$. Values are means \pm S.E.M. for five animals per group. Different letters indicate a significantly different value $(P \leq 0.01)$.

of $\mathrm{NO}$, which is also produced in larger amounts and for a longer period of time compared with the constitutive isoforms (Forstermann et al. 1995).

The marked down-regulation of luteal eNOS mRNA from day 15 of pseudopregnancy onward suggests a lowered RNA synthesis of the gene or, alternatively, an increased eNOS mRNA destabilisation, although it may simply reflect the dynamic changes of the heterogeneous luteal cell population occurring in the course of the $\mathrm{CL}$ life span (Nicosia et al. 1995). By contrast, the mRNA levels encoding iNOS were barely detectable and no agerelated trend was traced throughout late luteal stages of pseudopregnancy and during both phases of luteal regression. In rabbit $\mathrm{CL}$, immunohistochemical staining revealed that iNOS is localised only in a few immune cells (Boiti et al. 2002) and thus the low levels of iNOS mRNA may be partially explained by the variable presence of a small number of activated macrophages.

Recent evidences based on in vitro experiments indicate that some of the cytokines here examined may also regulate NOS expression and activity depending on cell type, cytokine and NOS isoform (Gross \& Levi 1992). IL-2 was shown to promote eNOS mRNA (Juretic et al. 1995), whereas IL-1 $\beta$ augmented NOS activity in ovarian dispersate of rats (Estevez et al. 2002). At the same time, IL-1 $\beta$ induces iNOS gene expression by activating the transduction factor nuclear factor-кB (Forstermann et al. 1995), but other ILs can inhibit its expression (Bogdan et al. 1994).

Besides cytokines, a large variety of agents including progesterone (Miller et al. 1996), cAMP-elevating compounds (Mustafa \& Olson 1998) and NO itself (Taylor et al. 1997) have been shown to inhibit cytokine-induced iNOS transcription in different cell lines. Thus, it is not clear at this time whether the up-regulation in luteal NOS activity during spontaneous luteolysis is associated with an induction of eNOS and/or iNOS genes and new protein synthesis around day 14 of pseudopregnancy, with increased substrate supply, or with other post-translational mechanisms (Boiti et al. 2001). Nevertheless, it is important to note that, despite the different time-scale employed to examine the two luteolytic processes, similar findings were observed also in PGF2 $\alpha$-induced luteolysis when NOS activity markedly rose within $6 \mathrm{~h}$ after PGF $2 \alpha$ challenge and remained high throughout the following $48 \mathrm{~h}$, whereas eNOS gene transcription decreased by $40 \%$ and that for iNOS remained unaffected (Boiti et al. 2003).

In the present study, the expression levels for p53 mRNA were markedly enhanced in day $15 \mathrm{CL}$. This finding documents that the apoptotic pathway is already activated, on a molecular level, at this luteal stage concurrently with functional luteolysis and precedes the morphological changes typical of cell death observed in $\mathrm{CL}$ at day 18 of pseudopregnancy (Nicosia et al. 1995). It is now well recognised that the p53 gene can induce apoptosis by modifying the balance between the anti- and pro-apoptotic related proteins, such as Bcl-2 and Bax, controlled by several genes (Reed 1998). The switch in the relative abundance of this gene appears coincidental with the marked increase in total NOS activity. This finding suggests that in vivo exposure to increased levels of NO, NO-derived peroxynitrite and/or other reactive oxygen species (ROSs) generated during luteolysis, may modulate luteal apoptosis through up-regulation of the p53 gene as already demonstrated by in vitro studies on luteal cells treated with $\mathrm{H}_{2} \mathrm{O}_{2}$ (Nakamura \& Sakamoto 2001). The transient increase of p53 transcription at day 15 of 
pseudopregnancy, however, is also coincident with progesterone decline. Thus, the marked up-regulation of p53 gene in $\mathrm{CL}$ may be triggered by removal of the progesterone blockade, which exerts a protective action on luteal cell survival and opposes functional regression of $\mathrm{CL}$ (Goyeneche et al. 2003).

Taken together, these results give strength to the hypothesis that the NO/NOS system is involved in $\mathrm{CL}$ regression in vivo as already documented for luteolysis induced by exogenous administration of PGF2 $\alpha$ (Boiti et al. 2003). In the ovary and luteal tissue, endogenous $\mathrm{NO}$, besides regulating the activity of key enzymes such as P450/scc, ADP-ribosylating enzymes, dehydrogenases, phosphatases and other transcription factors (Gow \& Ischiropoulos 2001), may also inhibit $17 \beta$-oestradiol synthesis (Yamauchi et al. 1997), which exerts a well-known luteotrophic action in rabbits (Holt 1989), or stimulate luteal PGF2 $\alpha$ release through the activation of cyclooxygenase (Estevez et al. 2002). Within the $\mathrm{CL}$, overproduction of $\mathrm{NO}$ during luteolysis may target nitration and oxidation in specific luteal cellular compartments thereby affecting specific protein function as well as causing lipid peroxidation (Aten et al. 1998, Motta et al. 2001) or DNA damage (Beckman et al. 1990). Moreover, high concentrations of NO may promote apoptosis (Kim et al. 1999).

In summary, the present data are consistent with the hypothesis that spontaneous luteolysis in rabbit $\mathrm{CL}$ is evoked through an up-regulation of NOS activity and increased release of $\mathrm{NO}$ and ROSs as already observed in luteal regression induced by exogenous PGF2 $\alpha$. Probably, the enhanced NOS activity is mediated by locally produced factors, including cytokines secreted by resident cells or recruited immune cells leading to apoptosis. It must be stressed, however, that a number of details of this proposed pathway are still unknown, including the exact sequence of events which, directly or indirectly, cause the up-regulation of NOS activity, and regulate the gene expression of NOS isoforms and those for cytokines MCP-1, IL-1 $\beta$ and IL-2 and p53. The up-regulation of MCP-1, IL-1 $\beta$ and p53 transcripts at day 15 post-ovulation is inversely correlated with the decrease in both plasma and luteal progesterone levels, suggesting that the removal of progesterone blockade may increase their transcription. Also the actions of these cytokines on luteal function, as well as their physiological relevance and the cross talk between immune cells and luteal cells remain to be better investigated. There is little doubt that complex interplay between different cytokines, due to their multiple and redundant actions, is at work in the $\mathrm{CL}$ during regression. Also, the signal interactions and the balance between pro- and anti-apoptotic proteins demand further investigation.

\section{Acknowledgements}

The authors gratefully acknowledge the revision of the English text by Dr James Burge of the Linguistic Institute of
Camerino University. This work was supported by a grant from Ministero dell'Istruzione, Università e Ricerca.

\section{References}

Aten RF, Kolodecik TR, Rossi MJ, Debusscher C \& Behrman HR 1998 Prostaglandin F2alpha treatment in vivo, but not in vitro, stimulates protein kinase C-activated superoxide production by nonsteroidogenic cells of the rat corpus luteum. Biology of Reproduction 59 1069-1076.

Bagavandoss P, Wiggins RC, Kunkel SL, Remick DG \& Keyes PL 1990 Tumor necrosis factor production and accumulation of inflammatory cells in the corpus luteum of pseudopregnancy and pregnancy in rabbits. Biology of Reproduction 42 367-376.

Bagavandoss P, Kunkel SL, Wiggins RC \& Keyes PL 1998 Tumor necrosis factor- $\alpha$ (TNF- $\alpha$ ) production and localization of macrophages and T lymphocytes in the rabbit corpus luteum. Endocrinology 122 1185-1187.

Beckman JS, Beckman TW, Chen J, Marshall PM \& Freeman BA 1990 Apparent hydroxyl radical production from peroxynitrite: implications for endothelial injury by nitric oxide and superoxide. PNAS 87 1620-1624.

Bogdan C, Vodovotz Y, Palk Xie QW \& Natham C 1994 Mechanism of suppression of nitric oxide synthase expression by interleukin-4 in primary mouse macrophages. Journal of Leukocyte Biology $\mathbf{5 5}$ $227-233$.

Boiti C, Zerani M, Zampini D \& Gobbetti A 2000 Nitric oxide synthase activity and progesterone release by isolated corpora lutea of rabbits in early- and mid-luteal phase of pseudopregnancy are differently modulated by prostaglandin $\mathrm{E}-2$ and prostaglandin F-2 alpha via adenylate cyclase and phospholipase C. Journal of Endocrinology 164 179-186.

Boiti C, Zampini D, Zerani M, Guelfi G \& Gobbetti A 2001 Prostaglandin receptors and role of $G$ protein-activated pathways on corpora lutea of pseudopregnant rabbit in vitro. Journal of Endocrinology 168 141-151.

Boiti C, Zampini D, Guelfi G, Paolocci F, Zerani M \& Gobbetti A 2002 Expression patterns of endothelial and inducible isoforms in corpora lutea of pseudopregnant rabbits at different luteal stages. Journal of Endocrinology 173 285-296.

Boiti C, Guelfi G, Zampini D, Brecchia G, Gobbetti A \& Zerani M 2003 Regulation of nitric oxide synthase isoforms and role of nitric oxide during prostaglandin F2alpha-induced luteolysis in rabbits. Reproduction 125 807-816.

Browning JY, Keyes PF \& Wolf RC 1980 Comparison of serum progesterone, 20 alpha-dihydroprogesterone, and estradiol-17beta in pregnant and pseudopregnant rabbits: evidence for postimplantation recognition of pregnancy. Biology of Reproduction 23 1014-1019.

Carlson JC \& Gole JWD 1978 CL Regression in the pseudopregnant rabbit and the effects of treatment with prostaglandin F-2alpha and arachidonic acid. Journal of Reproduction and Fertility 53 $381-387$.

Del Vecchio RP \& Sutherland WD 1997 Prostaglandin and progesterone production by bovine luteal cells incubated in the presence or absence of the accessory cells of the corpus luteum and treated with interleukin-1beta, indomethacin and luteinizing hormone. Reproduction, Fertility and Development 9 651-658.

Dixit VD \& Parvizi N 2001 Nitric oxide and the control of reproduction. Animal Reproduction Science 65 1-16.

Duncan DB 1955 Multiple range and multiple F test. Biometrics 11 $1-42$.

Estevez A, Tognetti T, Rearte B, Sander V \& Motta AB 2002 Interleukin-1beta in the functional luteolysis. Relationship with the nitric oxide system. Prostaglandins, Leukotrienes and Essential Fatty Acids 67 411-417.

Forstermann U, Gath I, Schwarz P, Closs EI \& Kleinert H 1995 Isoforms of nitric oxide synthase. Properties, cellular distribution 
and expressional control. Biochemical Pharmacology $\mathbf{5 0}$ $1321-1332$.

Gobbetti A, Boiti C, Canali C \& Zerani M 1999 Nitric oxide synthase acutely regulates progesterone production by in vitro cultured rabbit corpora lutea. Journal of Endocrinology $160275-283$.

Gow AJ \& Ischiropoulos H 2001 Nitric oxide chemistry and cellular signaling. Journal of Cellular Physiology 187 277-282.

Goyeneche AA, Deis RP, Gibori G \& Telleria CM 2003 Progesterone promotes survival of the rat corpus luteum in the absence of cognate receptors. Biology of Reproduction 68 151-158.

Gross SS \& Levi R 1992 Tetrahydrobiopterin synthesis. An absolute requirement for cytokine-induced nitric oxide generation by vascular smooth muscle. Journal of Biological Chemistry 267 $25722-25729$.

Holt JA 1989 Regulation of progesterone production in the rabbit corpus luteum. Biology of Reproduction 40 201-208.

Juretic A, Spagnoli CG, Horig H, Shipman R, Kucker T, Samija M, Turic M, Eljuga D, Harder F \& Heberer M 1995 Tyrosine kinasedependent and -independent events induced by interleukin-2 stimulation. Interleukin-2-mediated NO production required for the induction of lymphokine-activated killer cell activity in rat splenocytes is tyrosine kinase independent. Immunology $\mathbf{8 5}$ 325-330.

Kim YM, Bombeck CA \& Billiar TR 1999 Nitric oxide as a bifunctional regulator of apoptosis. Circulation Research 84 253-256.

Krusche CA, Vloet TD, Herrier A, Black S \& Beier HM 2002 Functional and structural regression of the rabbit corpus luteum is associated with altered luteal immune cell phenotypes and cytokine expression patterns. Histochemistry and Cell Biology 118 479-489.

Lotem J \& Sachs L 1999 Cytokines as suppressor of apoptosis. Apoptosis 4 187-196.

Miller L, Alley EW, Murphy WJ, Russell SW \& Hunt JS 1996 Progesterone inhibits inducible nitric oxide synthase gene expression and nitric oxide production in murine macrophages. Journal of Leukocyte Biology 59 442-450.

Motta AB \& Gimeno MA 1997 Nitric oxide participates in the corpus luteum regression in ovaries isolated from pseudopregnant rats. Canadian Journal of Physiology and Pharmacology $\mathbf{7 5}$ 1335-1339.

Motta AB, Estevez A, Franchi A, Perez-Martinez S, Farina M, Ribeiro ML, Lasserre A \& Gimeno MF 2001 Regulation of lipid peroxidation by nitric oxide and PGF2alpha during luteal regression in rats. Reproduction 121 631-637.

Mustafa SB \& Olson MS 1998 Expression of nitric-oxide synthase in rat Kupffer cells is regulated by cAMP. Journal of Biological Chemistry 273 5073-5080.
Naftalin DM, Bove SE, Keyes PL \& Townson DH 1997 Estrogen withdrawal induces macrophages invasion in the rabbit corpus luteum. Biology of Reproduction 56 1175-1180.

Nakamura T \& Sakamoto K 2001 Reactive oxygen species up-regulates cyclooxygenase-2, p53, and Bax mRNA expression in bovine luteal cells. Biochemical and Biophysical Research Communications 284 203-210.

Nicosia SV, Diaz J, Nicosia RF, Saunders BO \& Muro-Cacho C 1995 Cell proliferation and apoptosis during development and aging of the rabbit corpus luteum. Annals of Clinical Laboratory Science $\mathbf{2 5}$ 143-157.

Niswender GD, Juengel JL, Silva PJ, Rollyson MK \& McIntush EW 2000 Mechanisms controlling the function and life span of the corpus luteum. Physiological Review 80 1-29.

Pate JL \& Keyes PL 2001 Immune cells in the corpus luteum: friends or foes? Reproduction 122 665-676.

Penny LA 2000 Monocyte chemoattractant protein 1 in luteolyis. Review of Reproduction 5 63-66.

Reed JC 1998 Bcl-2 family proteins. Oncogene 17 325-336.

Schmidt HHHW \& Walter U 1994 NO at work. Cell 78 919-925.

Sokal RR \& Rohlf FJ 1981 Biometry, pp 253-261. New York: WH Freeman and Co.

Tamanini C, Basini G, Grasselli F \& Tirelli M 2002 Nitric oxide and the ovary. Journal of Animal Science 81 (Suppl 2) E1-E7.

Taylor BS, Kim YM, Wang Q, Shapiro RA, Billiar TR \& Geller DA 1997 Nitric oxide down-regulates hepatocyte-inducible nitric oxide synthase gene expression. Archives of Surgery 132 1177-1183.

Tilly JL 1996 Apoptosis and ovarian function. Review of Reproduction 1 162-172.

Torres M \& Forman HJ 2000 Nitric oxide, oxidative stress, and signal transduction. In Nitric Oxide, Biology and Pathobiology, pp 329-349. Ed. LJ Ignarro. San Diego: Academic Press.

Webb R, Woad KJ \& Armstrong DG 2002 Corpus luteum (CL) function: local control mechanism. Domestic Animal Endocrinology 23 277-285.

Yamauchi J, Miyazaki T, Iwasaki S, Kishi I, Kuroshima M, Tei C \& Yoshimura Y 1997 Effects of nitric oxide on ovulation and ovarian steroidogenesis and prostaglandin production in the rabbit. Endocrinology $1383630-3637$.

Received 24 July 2003

First decision 28 August 2003

Accepted 28 October 2003 